\title{
Jak dál s kurikulární reformou
}

\author{
Jana Straková \\ Univerzita Karlova, Pedagogická fakulta, Ústav výzkumu a rozvoje vzdělávání
}

Tento text vznikl v návaznosti na výroční konferenci České pedagogické společnosti Koncepce vzdělávání v české kurikulární diskuzi, která se konala v březnu 2013 v Liberci. V diskusním příspěvku formuluji své stanovisko ke kurikulární reformě a vyjadřuji se k tomu, jak by měla být dále rozvíjena. Domnívám se, že při přemýšlení o reformě je třeba zejména přemýšlet o tom, jak dál. Reflexe dosavadního průběhu reformy je důležitá pro identifikaci pochybení, kterých je třeba se v budoucnosti vyvarovat.

\section{Reflexe současného stavu}

Při hodnocení kurikulární reformy považuji za užitečné přemýšlet odděleně o kvalitě a potřebnosti záměru reformy a o jeho realizaci. Zamýšlím se tedy nad tím, (a) zda je reforma obecně potřebná, (b) zda má rozumné zacílení a (c) zda se podařilo cíle reformy kvalitně a efektivně zprostředkovat učitelům.

(a) Potřeba nových vzdělávacích cílů

V posledních desetiletích dochází v celém světě i v západní společnosti, jejíž jsme součástí, k dramatickým změnám. Tyto změny zpưsobují, že se mění také nároky na vědomosti, dovednosti i postoje, které jsou potřebné pro dobré uplatnění v osobním životě a pro úspěch na pracovním trhu. Moderní doba je charakterizována nebývalou dostupností informací. Rostoucí množství informací způsobuje, že není již důležité pouze to, co se dozvídáme, ale zejména jak se získanými informacemi naložíme. Řadu profesních dovedností, které byly dříve ceněny, nyní vykonávají moderní technologie. Statistiky ukazují pokles pracovních míst, která byla zaměřena na vykonávání rutinních manuálních a informačních služeb. Zároveň ukazují nárůst pracovních míst, která vyžadují komplexní komunikaci a expertní myšlení (Koenig, 2011). Ukazuje se, že pro úspěch na trhu práce již nestačí vědomosti a řemeslo, stále více se uplatňuje tvořivost, fantazie, sociální inteligence.

Globalizace pracovního trhu způsobuje, že uchazeči o pracovní př́ležitosti soutěží o pracovní uplatnění nejen s absolventy stejného vzdělávacího sys- 
tému, kteři jsou vybaveni podobnými vědomostmi a dovednostmi, ale že se potřebují uplatnit v daleko širší konkurenci. Globalizace způsobuje také velký pohyb pracovních příležitostí a přináší častější změny nejen pracovního místa, ale i vlastní profese, z čehož vyplývá potřeba osvojování si nových vědomostí a dovedností v průběhu celého života. K nutnosti stále se učit novým věcem vede i rychlý vývoj technologií, které ovlivňují nejen, kde a jak pracujeme, ale i jak komunikujeme se svými blízkými, jak nakupujeme, jak trávíme volný čas, jak si organizujeme osobní život.

Rostoucí složitost světa, který nás obklopuje, je provázena poklesem vlivu tradičních socio-kulturních a náboženských autorit, podle kterých se lidé dříve řídili. V moderních společnostech lidé musejí dělat stále složitější rozhodnutí a musejí se spoléhat pouze na svůj vlastní úsudek. Více než kdy dřive je důležité, aby byli lidé schopni kriticky posuzovat předkládané informace a uměli se rozhodovat na základě svých vlastních norem a přesvědčení.

Výše uvedené poznatky a argumenty vedly ve druhé polovině 20 . století mezinárodní komunitu tvưrců vzdělávacích politik k potřebě přehodnotit tradiční cíle vzdělávání a nově si položit otázku, jakými vědomostmi, dovednostmi a postoji má škola vybavovat své absolventy. Inspirativním počinem v této oblasti byl projekt Organizace pro hospodářskou spolupráci a rozvoj DeSeCo (Defining and Selecting Competencies), který se uskutečnil ve druhé polovině devadesátých let. Vymezení nových vzdělávacích cílů bylo založeno na východisku, že je nemožné předpovědět, jaké pracovní a životní úkoly přinese další vývoj. Z nemožnosti předvídat, jak bude vypadat svět v budoucnosti, vyplynul závěr, že školní vzdělávání musí místo předávání vědomostí a dovedností, které budou potřebovat $\mathrm{v}$ budoucnosti, žáky vybavit k tomu, aby uměli hledat vlastní řešení nyní neznámých úkolů, které jim život přinese. Důraz na vědomosti a dovednosti by měl být nahrazen kompetencemi ${ }^{1} \mathrm{k}$ jednání (Weinert, 2001). Těmto kompetencím je třeba se učit ve škole, na trhu práce je jejich získávání obtížnější. Ve škole si je mají žáci osvojovat také proto, že je potřebuje každý, bez ohledu na to, jakou profesi bude v životě vykonávat. Weinert zdůrazňuje, že tyto klíčové kompetence nemohou nicméně nahra-

\footnotetext{
Kompetence jsou zde definovány jako dovednost dostát požadavkům nebo úspěšně splnit úkol, který má kognitivní i nekognitivní složky. Kompetence podle této definice zahrnují kognitivní a praktické dovednosti, vědomosti, motivace, hodnotové orientace, přístupy, emoce a další sociální a behaviorální složky, které mohou být společně mobilizovány pro efektivní akci (např. kooperativní kompetence sestává z vědomostí, kognitivních dovedností, praktických dovedností, přístupů, emocí, hodnot a motivací, které se k této kompetenci vztahují).
} 
dit specifické vědomosti, a to zejména v případech řešení komplikovanějších úloh. Utopická je podle jeho názoru i představa, že člověk může pomocí několika klíčových kompetencí získat tyto specifické vědomosti v elektronických médiích. Pouze ti, kteří mají dostatečné počáteční vědomosti, jsou schopni efektivně využívat vědomostí nových (Weinert, 2001). ${ }^{2}$

Národní program rozvoje vzdělávání. Bílá kniha (2001) reflektoval (v souladu s mezinárodními diskusemi a trendy) vývoj ve společnosti a úkol vzdělávacího systému se tomuto vývoji přizpůsobit. Předjímal tvorbu nových vzdělávacích programů, v jejichž centru budou figurovat klíčové kompetence. Ty byly následně definovány a zařazeny jako hlavní vzdělávací cíle do rámcových vzdělávacích programů - závazných kurikulárních dokumentů.

Snaha nově vymezit vzdělávací cíle a posunout důraz na klíčové kompetence se nesetkala mezi učiteli s jednoznačně pozitivní odezvou. Dosud převažovaly spíše konzervativní tendence. ${ }^{3}$ Dostupné datové zdroje ukazují, že z hlediska cílů vzdělávání se dlouhodobě př́liš nezměnily ani priority veřejnosti. $\mathrm{V}$ posledních letech si rodičovská veřejnost nicméně začíná uvědomovat potřebu určitých změn v obsahu vzdělávání a vzdělávacích prioritách. $\mathrm{V}$ roce 2009 se dvě třetiny rodičů školních dětí vyslovily pro potřebu reforem. Rodiče požadují zlepšení práce školy v oblasti předávání morálních hodnot a respektu $\mathrm{k}$ pravidlům. Zároveň však reflektují potřebu změnit obsah a metody výuky, přičemž důraz je kladen zejména na oblast informačních technologií, ekonomiky a řízení a cizích jazyků (STEM/MARK, 2009).

Velmi skeptická je k potřebě inovací vzdělávacích cílů akademická komunita. Argumenty pro inovaci vzdělávacích cílů uvedené v úvodu této kapitoly byly obhájci kurikulární reformy a př́znivci modernizace školství tak často opakovány, až získaly v české akademické obci punc jakéhosi povrchního účelového klišé, kterému není třeba věnovat pozornost. Otázka potřeby inovací, případně jejich konkrétní podoby, není seriózně diskutována. Zároveň je této argu-

2 Kromě označení klíčové kompetence (key competencies) se setkáváme s řadou dalších termínů: kompetence/dovednosti pro 21. století (competencies for $21^{\text {st }}$ century / $21^{\text {st }}$ century skills), životní dovednosti (life skills) a podobně. Všechny tyto termíny označují v zásadě totéž.

3 Např. ve výzkumu učitelů v roce 2011 necelá polovina učitelů základních škol vyjádřila souhlas s tvrzením, že ve světě a společnosti dochází k préekotným změnám, dnešní žáci se ve škole musí učit něco zcela jiného, než se učili jejich rodiče, tři čtvrtiny učitelů pak vyjádřily souhlas s tvrzením, že obsah výuky a vyučovací metody na většině základních škol odpovídají požadavkům dnešního světa (Straková et al., 2013). 
mentaci často vytýkáno, že vychází primárně z potřeb pracovního trhu, případně potřeb praktického života a nebere v potaz kultivační funkci vzdělávání.

I když jsou výše uvedené výhrady vzhledem ke kontextu diskuse pochopitelné, nemění nic na skutečnosti, že potřeby českých mladých lidí jsou stejné jako potřeby mladých lidív ostatních vyspělých zemích a že českývzdělávacísystém nemůže dramatické změny ve společnosti ignorovat. Při obhajobě změn je ovšem třeba více zdůrazňovat, že modernizace cílů nepředstavuje radikální zavržení tradičních vědomostí a dovedností, ale jejich obohacení, rozšíření. Mnohé z klíčových kompetencí uváděných $\mathrm{v}$ mezinárodních i českých dokumentech zároveň slouží nejen k uplatnitelnosti na pracovním trhu, ale velkou měrou rovněž $\mathrm{k}$ intelektuální kultivaci. To platí typicky například o kompetenci $\mathrm{k}$ řešení problémů, kritickém myšlení a metakognitivních dovednostech. Ty byly $\mathrm{v}$ českém kurikulu tradičně zanedbávány. Je možné (a bylo by to jistě užitečné) diskutovat o tom, jakým klíčovým kompetencím je třeba věnovat největší pozornost, na modernizaci vzdělávacích cílů však není možno rezignovat. V tomto smyslu byla kurikulární reforma bezesporu krokem správným směrem.

\section{(b) Vymezení nových vzdělávacích cílů}

Významným př́íspěvkem ke specifikaci cílů vzdělávání v moderní společnosti byla práce Mezinárodní komise pro vzdělávání pro 21. století, která pracovala pod vedením Jacquese Delorse při organizaci UNESCO. Její zpráva Learning: The treasure within (Delors et al., 1996) vymezila čtyři základní cíle vzdělávání pro moderní společnost: učit se znát, učit se konat, učit se žít s ostatními a učit se být. Autoři zdůraznili, že vzdělávací systémy mají tendenci upřednostňovat nabývání vědomostí na úkor ostatních typů učení a že nyní je však zásadní pojmout vzdělávání šířeji. Učení nesmí zanedbat žádný aspekt lidského potenciálu: pamět', logickou argumentaci, estetický smysl, fyzické dovednosti, komunikační dovednosti.

Autoři již zmiňovaného projektu DeSeCo doporučili se soustředit na kompetence, které jsou důležité $\mathrm{v}$ různých oblastech života a které přispívají k celkově úspěšnému životu a dobře fungující společnosti. Volba klíčových kompetencí podle nich závisí na tom, co uznává ta která společnost (je třeba volit ty, které posilují společenský, ekonomický a osobní úspěch). Normativní bázi pro výběr by měly tvořit lidská práva, demokratické hodnoty a snaha o udržitelný rozvoj. Mezi cíle na individuální úrovni patří: př́ístup k ekonomickým zdrojům, politická participace, přístup k intelektuálním zdrojům, 
zapojení do sociálních sítí, blízké vztahy s druhými, fyzické a psychické zdraví, osobní bezpečnost a pocit úspěchu a radosti. Na úrovni společenské pak: mír a bezpečnost, rovnost bez diskriminace, ekonomická produktivita, demokratické procesy, společenská soudržnost, lidská práva a udržitelný rozvoj.

Podle názorů autorů vyžaduje dnešní doba kritické myšlení a přemýšlivý, holistický přístup k životu, který se vyznačuje vzrůstající komplexitou a vzájemnými souvislostmi mezi aktuálními jevy. Člověk musí být schopen pohlédnout s odstupem na požadavky, které na něj klade prostředí, učinit samostatný úsudek, řídit své vlastní konání a poměřovat je svými city, myšlenkami, hodnotami, aktivně jednat a nenechat se vláčet okolnostmi a jinými osobami, určovat svůj život.

Na výše uvedené zásadní práce navázali další autoři s pokusy o strukturaci klíčových kompetencí. ${ }^{4} \mathrm{~V}$ principu se vždy jedná o tři okruhy kompetencí: kognitivní kompetence (typicky řešení nerutinních problémů, systémové myšlení, kritické myšlení), kompetence sociální (komplexní komunikace, sociální dovednosti, týmová práce, kulturní citlivost, přijímání odlišností, občanské kompetence) a kompetence personální (sebeřízení, hospodaření s časem, vlastní rozvoj, sebekontrola, adaptabilita, schopnost jednat; viz např. Koenig, 2011).V některých členěních se ještě explicitně objevuje kompetence pracovní.

České rámcové vzdělávací programy pro povinné vzdělávání vymezují 6 klíčových kompetencí: kompetence k učení, kompetence k řešení problémů, kompetence komunikační, kompetence občanská, kompetence sociální a personální, kompetence pracovní. Tyto kompetence odpovídají výše uvedeným konceptům. I když by bylo jistě možno přemýšlet o jiném strukturování, umožňují klíčové kompetence specifikované v rámcových vzdělávacích programech zaměřit pozornost na důležité aspekty vzdělávání tak, jak jsou specifikovány v zahraničních dokumentech. Jejich relativně obecná formulace zajišt'uje, že mohou sloužit jako základ dalších konkrétnějších a promyšlenějších snah v oblasti vymezení klíčových kompetencí pro potřeby vyučování a učení.

Obhajoba potřeby modenizace cílů vzdělávání prostřednictvím klíčových kompetencí se může jevit banální. Vzhledem k debatě, která se o reformě

4 Mnozí autoři explicitně zdůrazňují, že tyto kompetence, které jsou formulovány nově v reakci na potřeby měnícího se světa, nejsou pro kvalitní vzdělávání dostatečné, a že je samozřejmé, že si žáci musí osvojit tradiční školní vědomosti a dovednosti. 
vede v akademické komunitě, však považuji za potřebné explictně říci, že modernizace vzdělávacích cílů je podle mého názoru potřebná a že klíčové kompetence představují nosný rámec pro formulaci cílů, kterých se v českém vzdělávání nedostává.

\section{(c) Implementace}

Zatímco z hlediska samotného konceptu i obsahu kurikulární reformy se názory aktérů jak na straně odborníků, tak na straně pedagogů liší, k vlastní implementaci reformy je drtivá většina aktérů shodně kritická. Kritizují malou propagaci myšlenek reformy, která znemožnila její přijetí učiteli i rodiči, a absenci podpory při její implementaci. Kritikům dávají za pravdu i výzkumy, které ukazují nedostatečné porozumění reformě všemi aktéry a rozporuplné postoje učitelů ke změnám, které reforma přináší. Často bývá kritizována i sama idea dvoustupňového kurikula, jehož cílem bylo zapojit učitele do přemýšlení o cílech a obsazích vzdělávání a poskytnout jim více autonomie pro jejich práci. Zatímco od některých pedagogických sborů se dozvídáme, že povinnost společně tvořit školní vzdělávací program pro ně byla užitečná, nebot' se naučily spolu diskutovat a přemýšlet, v př́ípadě mnohých sborů je zcela zřejmé, že úkol vytvořit vlastní vzdělávací program byl pojednán zcela formálně a přinesl jen malý užitek. Učitelé měli se zaváděním reformy mnoho práce a smysl této práce řadě z nich unikl (např. Janík \& Knecht, 2007; Janík et al., 2010; Straková, 2010).

Největší nedostatek implementace reformy spočívá podle mého názoru v přecenění profesní vyspělosti všech zapojených aktérů. „Nedostatečná“ vyspělost tvůrců dokumentů se projevila $\mathrm{v}$ tom, že v dokumentech poskytli učitelům málo vodítek, která by jim umožňovala nové vzdělávací cíle uchopit, prioritizovat a smysluplně zakomponovat do běžné výuky. Pravděpodobně proto, že i oni měli nejasnou představu o tom, jak by se měla reforma v běžných školách a třídách realizovat a jak by měly vypadat její výsledky, a tak trochu doufali, že odpověd' získají od samotných učitelů. „Nedostatečná“ vyspělost učitelů se pak projevila $\mathrm{v}$ tom, že většinově nepochopili reformu jako př́ležitost zvýšit užitečnost a smysluplnost své práce a modifikovat ji tak, aby z ní získali maximální pracovní uspokojení.

Adjektivum „nedostatečný“ zde není míněno pejorativně, ale věcně. Vyjadřuje názor, že aktéři nebyli připraveni na takto ambiciózní reformu. 
Analýza opatření vzdělávacích politik, kterou uskutečnila společnost McKinsey v souvislosti s analýzou dat z výsledků šetření PISA 2009 (Mourshed, Chijioke, \& Barber, 2010), přinesla zajímavé zjištění: mezi nejvyspělejšími vzdělávacími systémy dosahují lepších výsledků ty systémy, ve kterých mají školy a učitelé vyšší autonomii. V méně vyspělých vzdělávacích systémech je tomu naopak: systémy s vyšší autonomií jsou na tom hủře. Zdá se, že v systémech, kde nemají aktéři dostatečně promyšleno, jak vypadá kvalitní vyučování a učení a jak jej lze realizovat, neumějí autonomie efektivně využít. Výsledkem vyšší autonomie pak není efektivnější využití kapacit, ale chaos. Je možné, že česká kurikulární reforma je př́kladem tohoto jevu, tedy situace, kdy autonomie byla poskytnuta předčasně - v době, kdy ji aktéři neuměli dostatečně ocenit a využít. Zároveň vedla k poněkud povrchnímu uchopení konceptu změny, které mělo za následek často bezcílné a nepoučené experimentování s netradičními výukovými přístupy, jehož učební efekty byly přinejmenším problematické.

Dalším implementačním pochybením bylo nedostatečné využití všech dostupných kapacit. Podobu reformy i její implementaci zcela jistě negativně ovlivnilo malé zapojení fakult připravujících učitele ve fázi koncipování i realizace reformy - vysokoškolští pedagogové většinově nepřijali reformu za svou, nesnažili se přispět $\mathrm{k}$ její úspěšné realizaci ani pro její myšlenky získat budoucí učitele.

\section{Na co se zaměřit při podpoře reformy}

Na základě výše uvedených poznatků považuji za zásadní reformu nezpochybňovat a naopak zdůrazňovat její bezesporné aspekty, tedy potřebu přizpůsobit vzdělávací cíle a obsah vzdělávání změnám ve společnosti a zaměřit se přitom na klíčové kompetence specifikované v rámcových vzdělávacích programech. Zpochybňování reformy považuji za nebezpečné, nebot' sděluje učitelům, že práce, kterou $\mathrm{v}$ minulých letech investovali do realizace reformy, byla zcela zbytečná. Takové počínání dále podrývá již tak malou dủvěru pedagogů v moudrost tvůrců vzdělávacích politik a posiluje jejich demotivovanost. Považuji za důležité deklarovat, že na již vykonanou práci navazujeme a dále ji rozvíjíme, a skutečně to činit. I když implementaci reformy hodnotíme jako nepovedenou, měli bychom při přemýšlení o jejím pokračování brát v úvahu i její vzdělávací efekty a pozitiva, které přinesla do některých pedagogických sborů a potažmo i do celé pedagogické komunity. 
Při další podpoře reformy je podle mého názoru nutné se zaměřit na podporu její praktické realizace ve školách a třídách a důsledně vycházet z profesních možností učitelů. To znamená podporovat reformu metodicky prostřednictvím materiálů a vzdělávacích aktivit, které jsou pro učitele dosažitelné a které jsou jimi vnímány jako užitečné. Podpora musí směřovat zejména $\mathrm{k}$ tomu, aby učitelé porozuměli novým vzdělávacím cílům a aby si dovedli představit, jak přesně se projevuje jejich dosahování v konkrétní výuce jejich předmětu.

Oporou pro další kroky nám mohou být zahraniční zkušenosti, které ukazují, že cesta k takovému porozumění vede přes dobrou specifikaci vzdělávacích cílů (která vzniká ve spolupráci odborníků a učitelů) a podporu hodnocení míry jejich dosahování.

Podpora hodnocení se zdá být důležitá také proto, že jejím prostřednictvím je možno zacílit pozornost vzdělavatelů. Organizátoři mezinárodních i národních měření vědomostí a dovedností si začínají rostoucí měrou uvědomovat, že obsah měření a způsob, jakým jsou prezentovány výsledky, zásadním způsobem ovlivňují obsahy i metody vzdělávání v mezinárodním i národních kontextech. Učitelé, ve snaze zlepšit výsledky svých žáků v testech, věnují zvýšenou pozornost vědomostem a dovednostem, které jsou hodnoceny. Mnohdy tak činí na úkor jiných vědomostí a dovedností, které hodnoceny nejsou. Proto roste snaha co nejvíce rozšírit rozsah vědomostí a dovedností ověřovaných $\mathrm{v}$ plošných testech a obohatit je právě o cíle odpovídající klíčovým kompetencím. ${ }^{6}$

Velká pozornost je věnována zejména nekognitivním dovednostem, nebot' se má za to, že jejich význam pro uplatnění na trhu práce a v životě ve 21 . století je minimálně stejně tak velký jako význam dovedností kognitivních a zároveň je jejich hodnocení obtížnější. Skutečnost, že je neumíme objektivně hodnotit, vede k tomu, že jsou ve výuce mnohdy opomíjeny. Proto některé systémy zahrnují měření nekognitivních výstupů do národních monitoringů realizovaných prostřednictvím výběrových šetření. $V$ takových šetřeních mohou být části žáků administrovány úlohy, jejichž vyhodnocování je zatíženo určitou

6 Jako př́klad takové iniciativy je možno uvést Assessment and Teaching of $21^{\text {st }}$ Century Skills sponzorovaný společnostmi Microsoft, Intell a Cisco, jejichž ambicí je vyvinout počítačové úlohy na skupinové řešení problémových úkolů (collaborative problem solving). Zajímavý příspěvek do debaty o měření nekognitivních kompetencích přinesla multioborová pracovní skupina Committee on the Assessment of $21^{\text {st }}$ Century Skills, která ukázala, jak je možno měřit nejen kognitivní, ale též nekognitovní dovednosti (Koenig, 2011). 
mírou subjektivity, tedy kde například dochází k vyhodnocování výkonů žáků hodnotiteli. Při vhodném výběru žáků poskytuje tento postup informaci o tom, jak vypadá osvojení př́śslušných kompetencí v rámci celého systému a zároveň ukazuje učitelům, jak je možno tyto kompetence hodnotit (a tedy i rozvíjet).

Učitelům jsou k dispozici úlohy spolu s přesnými popisy ověřovaných vzdělávacích cílů, s návody na jejich vyhodnocení a s ukázkovými žákovskými pracemi, které jsou podle těchto návodů vyhodnoceny. Tyto úlohy mohou učitelé používat ve své výuce. Snaží-li se učitelé hodnotit úlohy podle přiložených návodů, učí se rozpoznávat znaky, podle kterých lze výkon žáků posuzovat, a budují společné porozumění tomu, jak vypadá výkon žáka, který si osvojil danou dovednost. Tím se sjednocuje pohled na cíle vzdělávání a jejich naplňování v celé odborné komunitě. Na základě podrobně popsaných cílů pak mohou učitelé také poskytovat žákům podrobnou zpětnou vazbu $\mathrm{k}$ jejich výkonu a pokroku (Nusche et al., 2013).

Vydá-li se Česká republika cestou konkretizace cílů a podpory jejich společnému porozumění a hodnocení, měly by se do procesu popisu vzdělávacích cílů a vývoje úloh zapojit zvýšenou měrou fakulty připravující učitele. Zapojení těchto fakult je nezbytné z toho důvodu, že do procesu mohou vnést potřebnou odbornost a nabyté zkušenosti využít v př́ípravě budoucích učitelů.

\section{Literatura}

Delors, J. (1998). Learning: The treasure within - report to UNESCO of the International Commission. Paris : UNESCO.

Janík, T., \& Knecht, P. (2007). Pedagogický výzkum a kurikulární reforma české školy. In R. Jandová (Ed.), Svět výchovy a vzdělávání v reflexi současného pedagogického výzkumu. České Budějovice: JČU. [CD-ROM]. Dostupné z http://www.ped.muni.cz/weduresearch/ publikace/0004.pdf

Janík T., Janko, T., Knecht, P., Najvar, P., Pavlas, T., Slavík, J., Solnička, D., \& Vlčková, K. (2010). Kurikulární reforma na gymnáziích. Výsledky dotazníkového šetření. Praha: VÚP.

Koenig, J. A. (Ed.). (2011). Assessing 21 st century skills. Washington: National Academies Press. Dostupné z http://www.nap.edu/catalog.php?record_id=13215

Mourshed, M., Chijioke, C., \& Barber, M. (2010). How the world's most improved countries keep getting better. London: McKinsey.

Národní program rozvoje vzdělávání. Bílá kniha. (2001). Praha: MŠMT.

Nusche, D., Radinger, T., Santiago, P., \& Shewbridge, C. (2013). Synergies for better learning: An international perspective on evaluation and assessment. Paris: OECD.

Rychen D. S., \& Salganik L. H. (Eds.). (2001). Defining and selecting key competencies. Göttingen: Hogrefe \& Huber Publishers. 
STEM/MARK (2009). Sociologický výzkum zaměřený na analýzu struktury postojů a očekávání veřejnosti v oblasti školství, výchovy a vzdělávání. Praha: STEM/MARK.

Straková, J. (2010). Postoje českých učitelů k hlavním prioritám vzdělávací politiky. In R. Váňová \& H. Krykorková (Eds.), Učitel v současné škole (s. 167-175). Praha: FF UK.

Straková, J., Spilková, V., Friedleandaerová, H., Hanzák, T., \& Simonová, J. (2013). Názory učitelů základních škol na potřebu změn ve školním vzdělávání. Orbis scholae, (7)1, 79-100.

Weinert, F. E. (2001). Concepts of competence: A conceptual clarification. In D. S. Rychen \& L. H. Salganik (Eds.), Defining and selecting key competencies (s. 46-65). Göttingen: Hogrefe \& Huber Publishers.

Matoušek, O. (2013). Encyklopedie sociální práce. Praha: Portál.

Encyklopedie sociální práce přináší přes 200 hesel ze všech oblastí sociální práce. Publikace je postavena na interakčním pojetí sociální práce. Jedinečnost sociální práce spočívá $\mathrm{v}$ tom, že operuje v poli mezi klientem a jeho sociálním prostředím; pracovník je $\mathrm{v}$ obecném smyslu mediátorem mezi jednotlivcem a společností. Jeho úkolem je napomáhat sociálnímu fungování klientů a pomáhat společnosti, aby citlivě reagovala na potřeby svých členů. Tato dvojitá mediační role je role angažovaná. Je zakotvená hodnotově $\mathrm{v}$ náboženství nebo $\mathrm{v}$ humanitních ideálech. $\mathrm{V}$ podobě tematicky uspořádaných samostatných hesel poskytuje toto rozsáhlé dílo přehled psychologických a sociologických teorií a přístupů s dopadem do sociální práce, náboženský, filozofický a společenský kontext oboru. Přináší přehled klíčových pojmů, technik a metod sociální práce, ohrožených skupin a poskytovaných služeb. Samostatnou část tvoří hesla charakterizující profesi sociálního pracovníka a hesla zabývající se výzkumem v oblasti sociální práce. Encyklopedie reflektuje domácí vývoj oboru v evropském kontextu a zohledňuje i širší mezinárodní zřetel. Hesla popisují daný jev a jeho historii, hodnotová východiska, aplikační možnosti a výzkum.

\section{Ochrana, F. (2013). Metodologie vědy. Praha: Karolinum.}

Publikace se zabývá klíčovými problémy metodologie vědy. Metodologie vědy je pojímána jako teorie vědeckých metod a vědeckých postupů, jak dané vědecké metody používat ve vědeckém zkoumání a při budování vědeckých teorií. Podrobněji je zkoumán axiomaticko-deduktivní a induktivní př́ístup při budování vědecké teorie. Je analyzována role explanace a predikce ve vědeckém zkoumání a role narace v sociálních vědách. Na základě metody komparace je porovnávána vědecká explanace, interpretační výklad v sociálních vědách a definována východiska integrativního přístupu ke zkoumání sociálních jevů. Součástí publikace je slovník základních pojmů, věcný rejstř́k a seznam literatury. Kniha je vhodnou studijní pomůckou pro studenty nefilosofických fakult, zejména sociálních věd, jakož i všechny zájemce, kteří se chtějí seznámit s klíčovými problémy filosofie a metodologie vědy. 